\title{
Prevalence of antibiotic ( $\beta$-lactams, tetracycline, metronidazole, erythromycin) resistance genes in periodontic infections
}

\author{
Daniel Freitas $^{1}$, Lara Gonçalves ${ }^{1}$, Maria João Coelho ${ }^{1,2}$, Maria Pia Ferraz ${ }^{1,2}$, Ricardo Magalhães ${ }^{1,2}$, Cristina Pina ${ }^{1,2}$ and Inês Lopes Cardoso ${ }^{1,2 *}$ \\ ${ }^{1}$ Health Sciences Faculty, Fernando Pessoa University, Porto, Portugal \\ ${ }^{2}$ FP-ENAS/CEBIMED, Energy, Environment and Health Research Unit/Biomedical Research Centre, University Fernando Pessoa, Porto, Portugal
}

\begin{abstract}
Objective: Porphyromonas gingivalis and Prevotella intermedia are thought to be pathogens in adult periodontitis. Antibiotherapy is usually needed in the treatment of periodontitis being often prescribed empirically. To allow prescription of a specific antibiotic treatment, identification of resistance genes should be performed. The aim of this study was the identification of the presence of TetM, TetQ, TEM, $c f x A, M e f A, E r m B$ and Nim resistance genes in previously identified P. intermedia and $P$. gingivalis isolated from samples collected from periodontal infections.
\end{abstract}

Method: PCR was used for the identification of TetM, TetQ, TEM, $c f x A$, MefA, ErmB and Nim resistance genes in strains isolated from samples collected from periodontal infections.

Results: It was seen that $8 \%$ of isolates had one of the tested tetracycline resistance genes. A total of $32 \%$ of $\beta$-lactamases resistance genes was observed in isolated strains. It was also observed that $2 \%$ of isolates had one of the analysed erythromycin resistance genes. None of the isolates showed the presence of the metronidazole resistance gene.

Conclusions: Most strains harboring $\beta$-lactamase resistance genes had been previously identified as $P$. intermedia. No tetracycline resistance gene and a very low percentage of $\beta$-lactamase resistance genes were observed in $P$. gingivalis strains.

\section{Introduction}

The oral cavity constitutes a special environment in which more than 700 commensal or resident bacterial species, may store and exchange their genetic material [1]. Two of the most common human diseases (caries and inflammatory periodontal disease) result from the accumulation of bacterial biofilms (plaques) on tooth surfaces. Oral health is the result of a balance between the resident flora and defence systems of the host. When this balance is disturbed, commensal and transient bacteria will be responsible for various local infections [1]. Black-pigmented, Gram negative oral anaerobes such as Porphyromonas gingivalis and Prevotella intermedia are thought to be pathogens in adult periodontitis $[2,3]$. These bacteria are frequently isolated from patients under periodontitis treatment. Odontogenic local infections require surgical treatment and, if required, a probabilistic antibiotherapy is needed that is effective on most recognized oral pathogens [4].

Treatment of this infection is primarily probabilistic, favoring $\beta$-lactam, macrolide-lincosamide-streptogramin and nitromidazole antibiotic families. $\beta$-Lactams (especially amoxicillin) are used as the first-line treatment against infections of the oral cavity, because of their suitable antimicrobial spectrum, bactericidal activity, low incidence of adverse effects, and cost-effectiveness [1,5]. Intensive or inadequate use of $\beta$-lactam antibiotics in medicine and dentistry favors the selection of bacteria that have acquired resistance to other antibiotics [1].

In most cases, antibiotic prescription is empirical and based on the clinical condition of the patient. As a result, treatment is often inappropriate and leads to the development of bacterial resistance and even multiple resistances [6]. $\beta$-Lactams (especially amoxicillin) are used as the first-line treatment against infections of the oral cavity, but, the intensive or inadequate use of $\beta$-lactam antibiotics in medicine and dentistry favors the selection of bacteria that have acquired resistance to other antibiotics. Antibiotic resistance genes gradually spread among other pathogenic bacterial species by horizontal gene transfer in resident or transient bacterial populations. So, antibiotic resistance has become a serious problem in nowadays medical and dental practice, and data from the literature suggest that antibiotic resistance in the periodontal microbiota has increased.

The main mechanism of resistance to $\beta$-lactam antibiotics in the oral cavity appears to be production of a $\beta$-lactamase. This enzyme is frequently detected in diseased periodontal sites and appears to be positively correlated with increased periodontal pocket depth.

For this reason, antibiotic resistances have been under extensive microbiological, biochemical and genetic investigations [4].

${ }^{*}$ Correspondence to: Inês Lopes Cardoso, Faculdade de Ciências da Saúde, Universidade Fernando Pessoa Rua Carlos da Maia, 296, 4200-150 Porto, Tel: 351 225071300; E-mail: mic@ufp.edu.pt

Key words: antibiotic resistance genes, periodontic infections, $\beta$-lactamase, tetracycline, metronidazole, erythromycin

Received: October 09, 2019; Accepted: October 29, 2019; Published: November 01, 2019 
$\beta$-Lactamases produced by oral Gram-negative bacilli belong to Ambler class A (CepA, CblA, CfxA, CSP-1 and TEM), class B (CfiA) or class D (FUS-1).

Reports from different countries show an increasing prevalence of patients with oral and subgingival $\beta$-lactamase producing bacteria. The use of antibiotics (defined as daily doses/100 000 inhabitants) was significantly higher in Mediterranean countries than in the rest of Europe [7,8]. However, in Portugal there is no data concerning antibiotic resistance of oral flora. Little is known about the variety of $\beta$-lactamases in periodontal isolates [9].

The determination of in vitro antimicrobial susceptibility can be important in certain situations, for example, to monitor patterns of susceptibility and resistance in the population and to help in the selection of the appropriate antibiotic in dentistry treatment [10]. Although antibiotic sensitivity can be determined from standard cultural microbiological analysis, this generally takes several days due to the slow growth of fastidious anaerobic bacteria. Since infection can spread rapidly and cause severe complications such as sepsis and obstruction of the airway, such a delay can prove problematic and undesirable. The introduction of PCR-based techniques has resulted in the development of tests that can detect specific pathogens and genes directly and rapidly from clinical samples. Indeed, conventional PCR has already become an important tool in clinical diagnostic and research laboratories [5].

The main goal of this study was to identify the presence of antibiotic resistance genes in strains isolated from periodontal infections. These strains had been previously identified as $P$. intermedia and $P$. gingivalis. Analyzed genes were TetM and TetQ genes that confer resistance to tetracycline, $c f x A$ and TEM genes giving resistance to $\beta$-lactamases, nim gene responsible for metronidazole resistance and $\operatorname{erm} B$ and mef $A$ genes involved in erythromycin resistance. These correspond to the most frequently prescribed antibiotics for periodontitis treatment.

\section{Methods}

This study was based on 50 adult patients with ages ranging from 35 to 75 years old, having a diagnosis of periodontitis and that did not receive antimicrobial therapy in the previous 30 days. The sampling was done in a clinical of oral medicine in a Portuguese University School.

Isolation and identification of bacterial strains had been previously performed [11].

For the identification of the tetracycline resistance genes, DNA (5 $\mu \mathrm{L}$ ) was amplified in a reaction mixture containing $10 \mu \mathrm{L}$ of $5 \mathrm{x}$ PCR buffer, $3 \mu \mathrm{L}$ of $\mathrm{MgCl}_{2} 25 \mathrm{mM}, 1 \mu \mathrm{L}$ of dNTP mixture $10 \mathrm{mM}, 2,5 \mu \mathrm{L}$ of each primer $10 \mu \mathrm{M}$ and $0,25 \mu \mathrm{L}$ Taq polymerase in a total volume of 50 $\mu \mathrm{L}[12]$.

Primers used for identification of the TetM gene were $5^{\prime}$-GACACGCCAGGACATATGG-3' and 5'-TGCTTTCCTCTTGTTCGAG-3' [12]. PCR was performed according with Koukos, et al. [12] as followed: 5 minutes at $94^{\circ} \mathrm{C} ; 37$ cycles of 30 seconds at $94^{\circ} \mathrm{C}, 1$ minute at $55^{\circ} \mathrm{C}$ and 90 seconds at $72^{\circ} \mathrm{C}$; final extension for 10 minutes at $72^{\circ} \mathrm{C}$.

Primers used for identification of the TetQ gene were 5'-GGCTTCTACGACATCTATTA-3' and 5'-CATCAACATTTATCTCTCTG-3' [12]. PCR was performed according with Koukos, et al. [12] as followed: 5 minutes at $94^{\circ} \mathrm{C} ; 37$ cycles of 30 seconds at $94^{\circ} \mathrm{C}, 1$ minute at $50^{\circ} \mathrm{C}$ and 160 seconds at $72^{\circ} \mathrm{C}$; final extension for 10 minutes at $72^{\circ} \mathrm{C}$.
For identification of the TEM gene, DNA $(5 \mu \mathrm{L})$ was amplified in a reaction mixture containing $10 \mu \mathrm{L}$ of $5 x$ PCR buffer, $4 \mu \mathrm{L}_{\text {of }} \mathrm{MgCl}_{2} 25 \mathrm{mM}$, $2 \mu \mathrm{L}$ of dNTP mixture $10 \mathrm{mM}, 5 \mu \mathrm{L}$ of each primer $10 \mu \mathrm{M}$ and $0,25 \mu \mathrm{L} \mathrm{Taq}$ polymerase in a total volume of $50 \mu \mathrm{L}$ [12]. Primers used for identification of the TEM gene were 5'-AGATCAGTTGGGTGCACGAG-3' and 5'-CAGTGCTGCAATGATACCGC-3' [12]. PCR was performed according with Koukos, et al. [12] as followed: 5 minutes at $94^{\circ} \mathrm{C} ; 35$ cycles of 1 minute at $94^{\circ} \mathrm{C}, 1$ minute at $62^{\circ} \mathrm{C}$ and 1 minute at $72^{\circ} \mathrm{C}$; final extension for 10 minutes at $72^{\circ} \mathrm{C}$.

For identification of the $c f x A$ gene, DNA $(5 \mu \mathrm{L})$ was amplified in a reaction mixture containing $10 \mu \mathrm{L}$ of $5 \mathrm{x}$ PCR buffer, $4 \mu \mathrm{L}$ of dNTP mixture $10 \mathrm{mM}, 5 \mu \mathrm{L}$ of each primer $10 \mu \mathrm{M}$ and $0,25 \mu \mathrm{L}$ Taq polymerase in a total volume of $50 \mu \mathrm{L}$. Primers used for identification of the $c f x A$ gene were 5'-GCAAGTGCAGTTTAAGATT-3' and 5'-GCTTTAGTTTGCATTTTCATC-3' [9]. PCR was performed according with Handal, et al. [9] as followed: 5 minutes at $94^{\circ} \mathrm{C} ; 25$ cycles of 1 minute at $94^{\circ} \mathrm{C}, 1$ minute at $58^{\circ} \mathrm{C}$ and 30 seconds at $72^{\circ} \mathrm{C}$; final extension for 10 minutes at $72^{\circ} \mathrm{C}$.

For identification of the nim gene, DNA $(5 \mu \mathrm{L})$ was amplified in a reaction mixture containing $10 \mu \mathrm{L}$ of $5 \times$ PCR buffer, $3 \mu \mathrm{L}$ of $\mathrm{MgCl}_{2} 25 \mathrm{mM}$, $1 \mu \mathrm{L}$ of dNTP mixture $10 \mathrm{mM}, 5 \mu \mathrm{L}$ of each primer $10 \mu \mathrm{M}$ and $0,25 \mu \mathrm{L} \mathrm{Taq}$ polymerase in a total volume of $50 \mu \mathrm{L}$ [12]. Primers used for identification of the nim gene were 5'-ATGTTCAGAGAAATGCGGCGTAAGCG-3' and 5'-GCTTCCTTGCCTGTCATGTGCTC-3' [12]. PCR was performed according with Koukos, et al. [12] as followed: 5 minutes at $94^{\circ} \mathrm{C} ; 35$ cycles of 30 seconds at $94^{\circ} \mathrm{C}, 1$ minute at $62^{\circ} \mathrm{C}$ and 1 minute at $72^{\circ} \mathrm{C}$; final extension for 10 minutes at $72^{\circ} \mathrm{C}$.

For identification of the ermB and mefA genes, DNA $(1 \mu \mathrm{L})$ was amplified in a reaction mixture containing $4 \mu \mathrm{L}$ of $5 \mathrm{x}$ PCR buffer, $0,4 \mu \mathrm{L}$ of $\mathrm{MgCl}_{2} 25 \mathrm{mM}, 0,8 \mu \mathrm{L}$ of dNTP mixture $10 \mathrm{mM}, 1 \mu \mathrm{L}$ of each primer 10 $\mu \mathrm{M}$ and $0,25 \mu \mathrm{L}$ Taq polymerase in a total volume of $20 \mu \mathrm{L}$ [13]. Primers used for identification of the ermB gene were 5'-CGTACCTTGGATATTCACCG-3' and 5'-GTAAACAGTTGACGATATTC-3' [13]. Primers used for identification of the mefA gene were 5'-CCCAGCTTAGGTATACGTAC-3' and 5'-CTGTATGGAGCTACCTGTCTGG-3' [13]. PCR was performed according with Ubukata, Iwata \& Sunakawa [14] as followed: 5 minutes at $94^{\circ} \mathrm{C} ; 30$ cycles of 20 seconds at $94^{\circ} \mathrm{C}, 20$ seconds at $52^{\circ} \mathrm{C}$ and 15 seconds at $72^{\circ} \mathrm{C}$; final extension for 10 minutes at $72^{\circ} \mathrm{C}$.

PCR products were analyzed by electrophoresis on a $1 \%$ agarose gel.

\section{Results and Discussion}

Concerning all tested antibiotic resistance genes, it was observed a total of $42 \%$ of antibiotic resistance genes in strains isolated from periodontal infections (Table 1). These results agree with most studies of other countries that show high levels of antibiotic resistance among anaerobes [12,15-18].

Analysis of $\beta$-lactamase resistance genes showed that $32 \%$ of total isolates harboured one of the analysed genes. From these, $2 \%$ corresponded to the presence of the $c f x A$ gene. These were identified as $P$. intermedia. The remaining $30 \%$ were strains harbouring the TEM gene. Most strains having the TEM gene were identified as Prevotella intermedia (20\%) while $8 \%$ belonged to unidentified black-pigmented species and $2 \%$ were $P$. gingivalis (Table 1).

Resistance genes identified in this study are in agreement with most published studies that report a high level of $\beta$-lactamase resistance in $P$. intermedia $[16,17]$, or lower prevalences of resistance $[4,19]$. However, 
Table 1. Results obtained in the identification of antibiotic resistance genes in strains previously isolated from periodontal infections

\begin{tabular}{|c|c|c|c|c|c|c|c|c|}
\hline \multicolumn{9}{|c|}{ Antibiotic Resistance Genes } \\
\hline \multirow[b]{2}{*}{ Strain } & \multirow[b]{2}{*}{$\begin{array}{l}\text { \% identified by } \\
\text { PCR }^{11}\end{array}$} & \multicolumn{2}{|c|}{ Tetracycline } & \multicolumn{2}{|c|}{$\beta$-Lactamases } & \multicolumn{2}{|c|}{ Erythromycin } & \multirow{2}{*}{$\begin{array}{c}\text { Metronidazole } \\
\text { Nim }\end{array}$} \\
\hline & & Tet $Q$ & Tet $M$ & $C f x A$ & $T E M$ & $\operatorname{ErmB}$ & MefA & \\
\hline$P$. gingivalis & $20 \%$ & $0 \%$ & $0 \%$ & $0 \%$ & $2 \%$ & $0 \%$ & $0 \%$ & $0 \%$ \\
\hline P. intermedia & $44 \%$ & $4 \%$ & $2 \%$ & $2 \%$ & $20 \%$ & $2 \%$ & $0 \%$ & $0 \%$ \\
\hline Other black-pigmented & $36 \%$ & $0 \%$ & $2 \%$ & $0 \%$ & $8 \%$ & $0 \%$ & $0 \%$ & $0 \%$ \\
\hline Total isolates & $100 \%$ & $4 \%$ & $4 \%$ & $2 \%$ & $30 \%$ & $2 \%$ & $0 \%$ & $0 \%$ \\
\hline
\end{tabular}

other studies also observe $\beta$-lactamase resistance in Porphyromonas sp. $[20,21]$, that was not detected in this study.

In agreement with this work, studies report high prevalence of the TEM gene (48-71\%) in periodontitis samples [22,23].

It has been reported that $c f x A$ and $c f x A 2$ occur in $100 \%$ of $\beta$-lactamase-positive Prevotella strains from American and Norwegian patients with periodontal disease [24]. French investigators have also demonstrated a $100 \%$ prevalence of the resistance genes in $\beta$-lactamasepositive Prevotella strains [5]. Some antibiotics, such as amoxicillinclavulanate, cefmetazole, clindamycin and metronidazole, have been demonstrated to be effective for treatment of $\beta$-lactamase-positive Prevotella infections.

$\beta$-Lactamases vary considerably from one organism to another. Some are chromosomally-encoded while others are plasmid-mediated; some are constitutive while others require induction [16]. The presence of resistance genes on plasmids and transposable elements allows resistance to be transferred even between genetically distantly related organisms [9].

Plasmid-specified $\beta$-lactamases are present in many Gram-negative bacteria. The most common of these is the TEM-type enzyme originally isolated from ampicillin-resistant Escherichia coli.

Concerning tetracycline resistance genes, it was observed that $8 \%$ of isolated strains had one of the analysed tetracycline resistance genes. The TetQ gene was detected in $4 \%$ of total isolates. The TetQ harbouring strains were all identified as $P$. intermedia. The TetM gene was also detected in $4 \%$ of total isolates, corresponding $1 \%$ of these to $P$. intermedia strains. The remaining $3 \%$ belonged to other blackpigmented unidentified strains. None of these tetracycline resistance genes was present in P. gingivalis strains (Table 1).

Ioannidis, et al. [22] also observed high levels of tetQ (70-80\%) and tetM (76-82\%) genes in samples collected from periodontal infections.

Moreover, unlike our data, another study [12] on implants showed that the most abundant genes were the tetracycline resistance genes. Collins, et al. [18] also detected seven tetracycline resistance genes in bacterial isolates from chronic periodontitis, including the tet $Q$ gene present in $72 \%$ of tested patients.

Isolated strains were also tested for the presence of the erythromycin resistance genes ermB and mefA. Only $2 \%$ of total isolates showed the presence of the ermB gene and none harboured the mefA gene (Table 1).

The nim gene, responsible for metronidazole resistance, was not detected in any of the isolates. Although, in accordance with this work, some studies did not detect the nim gene in collected samples [22,23], $\mathrm{Xie}$, et al. [25] reported the presence of this gene in strains isolated from periodontal abscesses.

$\beta$-Lactam resistance has been associated with resistance to tetracycline (Tet genes) and to erythromycin (erm genes) [26]. A recent study of oral anaerobes from patients with periodontitis identified a high prevalence (97\%) of $C f x A \beta$-lactamase production by aminopenicillinresistant Prevotella in subgingival plaque [9].

In the same way, it was observed in this work that strains with tetracycline resistance genes (TetQ or TetM) also harboured the TEM gene. Moreover, the ermB gene was detected in strains that also had the TEM and the TetM genes. These results may indicate a combined transfer of antibiotic resistance genes. However, due to the sampling size, these results should be confirmed with a bigger collection of sample isolates from periodontal infections.

Divergence in bacterial frequencies observed in this study and in other reports might be explained by geographical differences and divergences in sampling $[4,17]$ as well as sample size. This study should be enlarged to the analysis of a bigger number of patients carrying periodontal infections.

Due to the increasing prevalence of antibiotic resistance among bacterial strains isolated from periodontal infections, the empirical prescription of these antibiotics as a therapy strategy for periodontitis should be avoided.

This study contributes to the knowledge on subgingival microbiota and its resistance genes present in periodontal infections. Knowing the prevalence of resistance genes can have impact on their clinical prescription and might raise awareness to the appropriate use of antibiotics.

\section{Conclusion}

Our results showed that the genes coding for $\beta$-lactamases were the most prevalent resistance genes found in periodontal infections, with high prevalence of the TEM gene. Most resistance genes were found in strains previously identified as $P$. intermedia. This strain together with $P$. gingivalis are commonly isolated from periodontal infections being considered the most abundant putative black pigmented species $[2,4,9,11,18]$. When considering isolates from patients with periodontal disease, Prevotella sp. has been the most prevalent anaerobe isolate $[16,25]$. The presence of $\beta$-lactamases resistance genes in these strains is probably correlated with the fact that the $\beta$-lactams antibiotics are used as the first-line treatment in oral medicine.

As expected, oral bacterial species also carry in addition other resistance genes, such as tetracycline and erythromycin antibiotic resistance genes, probably due to the diversity of mechanisms of transfer of genetic material.

These results support the idea that the prescription of an antibiotic in oral medicine must be a carefully act based in clinical data, and not an empirical attitude, particularly in oral infections such as periodontitis.

\section{Funding}

This work was supported by national funds through FCT - Fundação para a Ciência e a Tecnologia, I.P. in the project UID/Multi/04546/2019. 


\section{Conflicts of interest}

The authors have stated explicitly that there are no conflicts of interest in connection with this article.

\section{Acknowledgement}

All authors have read and approved the final article.

\section{References}

1. Dupin C, Tamanai-Shacoori Z, Ehrmann E, Dupont A, Barloy-Hubler F, et al. (2015) Oral Gram-negative anaerobic bacilli as a reservoir of $\beta$-lactam resistance genes facilitating infections with multiresistant bacteria. Int J Antimicrob Agents 45: 99-105. [Crossref]

2. Andrés MT, Chung WO, Roberts MC, Fierro JF (1998) Antimicrobial susceptibilities of Porphyromonas gingivalis, Prevotella intermedia and Prevotella nigrescens spp. isolated in Spain. Antimicrob Agents Chemother 42: 3022-3023.

3. Gatignol JP, Poulet PP, Desse T, Duffaut D (2003) Comparison of laboratory methods for detecting $\beta$-lactamase positive strains in the species Prevotella intermedia sensu lato isolated from periodontal pockets. Eur J Clin Microbiol Infectious Dis 22: 389-391.

4. Fosse T, Madinier I, Hitzig C, Charbit Y (1999) Prevalence of $\beta$-lactamase-producing strains among 149 anaerobic Gram-negative rods isolated from periodontal pockets. Oral Microbiol Immunol 14: 352-357.

5. Iwahara K, Kuriyama T, Shimura S, Williams DW, Yanagisawa M, et al. (2006) Detection of cfxA and cfxA2, the $\beta$-lactamase genes of Prevotella spp., in clinica samples from dentoalveolar infection by real-time PCR. J Clin Microbiol 44:172-176.

6. Salinas MB, Riu NC, Aytés LB, Escoda CG (2006) Antibiotic susceptibility of the bacteria causing odontogenic infections. Med Oral, Patol Oral Cirur Bucal 11: E70-E75.

7. Van Winkelhoff AJ, Winkel EG (2005) Microbiological diagnostics in periodontics: biological significance and clinical validity. Periodontol 2000 39: 40-52.

8. Herrera D, van Winkelhoff AJ, Dellemijn-Kippuv N, Winkel EG, Sanz M (2000) $\beta$-lactamase producing bacteria in the subgingival microflora of adult patients with periodontitis. A comparison between Spain and The Netherlands. J Clin Periodontol 27: $520-525$.

9. Handal T, Olsen I, Walker CB, Caugant DA (2005) Detection and characterization of beta-lactamase genes in subgingival bacteria from patients with refractory periodontitis. FEMS Microbiol Lett 242:319-324.

10. Jacinto RC, Gomes BPFA, Shah HN, Ferraz CC, Zaia AA, et al. (2006) Incidence and antimicrobial susceptibilities of Porphyromonas gingivalis isolated from mixed endodontic infections. Int Endod J 39: 62-70.

11. Pina P, Cunha S, Silva R, Sousa JC, Lopes Cardoso I (2011) Antimicrobial susceptibilities of Porphyromonas and Prevotella species isolated from periodontitis infections in the north of Portugal. In: IV International Conference on Environmental, Industrial and applied Microbiology (BIOMICROWORLD2011). Málaga, Spain. Microbes in Applied Research: Current Advances and Challenges. World Scientific Publishing Co. Pte. Ltd, pp. 492-494.
12. Koukos G, Papadopoulos C, Tsalikis L, Sakellari L, Arsenakis M, et al. (2015) Prevalence of antibiotic resistance genes in subjects with successful and failing dental implants. A pilot study. Open Dent J 8: 257-263.

13. Najafi Mosleh M, Gharibi M, Alikhani MY, Saidijam M, Vakhshiteh F (2014) Antimicrobial susceptibility and analysis of macrolide resistance genes in Streptococcus pneumoniae isolated in Hamadan. Iran J Basic Med Sci 17: 595-599.

14. Ubukata K, Iwata S, Sunakawa K (2003) In vitro activity of new ketolide, telithromycin, and eight other macrolide antibiotics against Streptococcus pneumoniae having mefA and ermB genes that mediate macrolide resistance. J Infect Chemother 9: 221-226.

15. Handal T, Caugant DA, Olsen I (2003) Antibiotic resistance in bacteria isolated from subgingival plaque in the Norwegian population with refractory marginal periodontitis. Antimicrob Agents Chemother 47: 1443-1446.

16. Maestre JR, Bascones A, Sánchez P, Matesanz P, Aguilar L, et al. (2007) Odontogenic bacteria in periodontal disease and resistance patterns to common antibiotics used as treatment and prophylaxis in odontology in Spain. Rev Esp Quimioter 20: 61-67.

17. Dubreuil L, Behra-Miellet J, Vouillot C, Bland S, Sedallian A, et al. (2003) $\beta$-lactamase production in Prevotella and in vitro susceptibilities to selected $\beta$-lactam antibiotics. Int J Antimicrob Agents 21: 267-273.

18. Collins JR, Arredondo A, Roa A, Valdez Y, León R, et al. (2016) Periodontal pathogens and tetracycline resistance genes in subgingival biofilm of periodontally healthy and diseased Dominican adults. Clin Oral Investig 20: 349-356.

19. Mättö J, Asikainen S, Väisänen ML, von Troil-Lindén B, Könönen E, et al. (1999) $\beta$-lactamase production in Prevotella intermedia, Prevotella nigrescens and Prevotella pallens genotypes and in vitro susceptibilities to selected antimicrobial agents Antimicrob Agents Chemother 43: 2383-2388.

20. Montagner F, Jacinto RC, Signoretti FGC, Mattos VS, Grecca FS, et al. (2014) Betalactamic resistance profiles in Porphyromonas, Prevotella, and Parvimonas species isolated from acute endodontic infections. J Endod 40: 339-344.

21. Binta B, Patel M (2016) Detection of cfxA2, cfxA3, and cfxA6 genes in beta-lactamase producing oral anaerobes. J Appl Oral Sci 24: 142-147. [Crossref]

22. Ioannidis I, Sakellari D, Spala A, Arsenakis M, Konstantinidis A (2009) Prevalence of tetM, tetQ, nim and bla(TEM) genes in the oral cavities of Greek subjects: a pilot study. J Clin Periodontol 36: 569-574. [Crossref]

23. Koukos G, Konstantinidis A, Tsalikis L, Arsenakis M, Slini T, et al. (2016) Prevalence of $\beta$-lactam (bla TEM) and Metronidazole (nim) Resistance Genes in the Oral Cavity of Greek Subjects. Open Dent J 10: 89-98. [Crossref]

24. Ashimoto A, Chen C, Bakker I, Slots J (1996) Polymerase chain reaction detection of 8 putative periodontal pathogens in subgingival plaque of gingivitis and advanced periodontitis lesions. Oral Microbiol Immunol 11: 266-273.

25. Xie Y, Chen J, He J, Miao X, Xu M, et al. (2014) Antimicrobial resistance and prevalence of resistance genes of obligate anaerobes isolated from periodontal abscesses. J Periodontol 85: 327-334.

26. Falagas ME, Siakavellas E (2000) Bacteroides, Prevotella and Porphyromonas species: a review of antibiotic resistance and therapeutic options. Int $J$ Antimicrob Agents 15: $1-9$.

Copyright: (C2019 Freitas D. This is an open-access article distributed under the terms of the Creative Commons Attribution License, which permits unrestricted use, distribution, and reproduction in any medium, provided the original author and source are credited. 